\title{
Antimicrobial activity of hydroalcoholic extracts from genipap, baru and taruma
}

\author{
Fabíola Brandão dos Santos ${ }^{1 *}$ Maria Isabel Lima Ramos ${ }^{1}$ Luciana Miyagusku' $^{1}$
} ${ }^{1}$ Faculdade de Ciências Farmacêuticas, Alimentos e Nutrição (FACFAN), Universidade Federal do Mato Grosso do Sul (UFMS), 79070-900,
Campo Grande, MS, Brasil. E-mail: fabiolabrasan@gmail.com. "Corresponding author.

\begin{abstract}
Microbial resistance is a serious public health problem, which has led to the search for alternative treatments to replace antibiotics, including studies to evaluate the antimicrobial potential of species in Brazil's Cerrado. Therefore, the present study aimed to evaluate the antimicrobial activity of hydroalcoholic extracts of genipap, baru, and taruma against Staphylococcus aureus, Escherichia coli, Pseudomonas aeruginosa, and Candida albicans using disc diffusion tests and microdilution. Results indicated that all genipap extracts showed inhibition zones and minimum inhibitory concentrations (MICs) and minimum microbicidal concentrations (MMCs) ranging between $150 \mu \mathrm{g} / \mathrm{mL}$ and $940 \mu \mathrm{g} / \mathrm{mL}$ against all microorganisms tested. Baru pulp extracts exhibited larger inhibition zones against S. aureus and MIC and MMC results between $150 \mu \mathrm{g} / \mathrm{mL}$ and $1000 \mu \mathrm{g} / \mathrm{mL}$ against all microorganisms except P. aeruginosa. The taruma $30 \%$ pulp and seed extracts exhibited the largest halos against S. aureus and MIC and MMC results were between $150 \mu \mathrm{g} / \mathrm{mL}$ and $1000 \mu \mathrm{g} / \mathrm{mL}$ against all microorganisms except C. albicans. All fruits displayed potential for antimicrobial activity, particularly the genipap's pulp extracts. Further studies should be performed to identify compounds with antimicrobial activity and to test their applicability as preservatives in foods, as alternatives to antibiotic growth promoters, and as sanitizing agents.
\end{abstract} Key words: Cerrado fruits, antibiotics, Genipa americana, Dipteryx alata, Vitex cymosa.

Atividade antimicrobiana dos extratos hidroalcoólicos de jenipapo, baru e tarumã

RESUMO: A resistência microbiana é um sério problema de saúde pública que conduz a busca de alternativas de tratamentos em substituição aos antibióticos, entre elas, pesquisas para avaliar o potencial antimicrobiano de espécies existentes no Cerrado brasileiro. Assim a presente pesquisa teve como objetivo avaliar a atividade antimicrobiana dos extratos hidroalcoólicos de jenipapo, baru e tarumã frente à Staphylococcus aureus, Escherichia coli, Pseudomonas aeruginosa e Candida albicans, através dos testes de difusão em disco e microdiluição. Os principais resultados obtidos mostraram que todos os extratos de jenipapo tiveram halos de inibição e concentração inibitória mínima (MIC) e concentração microbicida mínima (MMC) que variaram entre $150 \mu \mathrm{g} / \mathrm{mL}$ a $940 \mu \mathrm{g} / \mathrm{mL}$ frente aos microrganismos testados. Os extratos da polpa de baru obtiveram maiores halos de inibição para S. aureus, no teste para MIC e MMC apresentaram resultados entre $150 \mu \mathrm{g} / \mathrm{mL}$ a $<1000 \mu \mathrm{g} / \mathrm{mL}$ para os microrganismos, exceto para P. aeruginosa. Os extratos de tarumã exibiram bons resultados, com destaque para os da polpa e da semente a $30 \%$, com maiores halos para $S$. aureus, obtiveram MIC e MMC com valores de $150 \mu \mathrm{g} / \mathrm{mL}$ a $<1000 \mu \mathrm{g} / \mathrm{mL}$ para todos os microrganismos, exceto para C. albicans. Todos os frutos apresentaram grande potencial para atividade antimicrobiana, em especial os extratos da polpa de jenipapo. Novos estudos devem ser elaborados com intuito de identificar os compostos com atividade antimicrobiana, além de ensaios de potencial farmacológico bem como sua aplicabilidade como conservantes em alimentos, substitutos de antibióticos promotores de crescimento e de agentes sanitizantes. Palavras-chave: frutos do Cerrado, antibióticos, Genipa americana, Dipteryx alata, Vitex cymosa.

\section{INTRODUCTION}

Microbial resistance has been widely discussed owing to the emergence of microorganisms resistant to currently available antibiotics (BARTH et al., 2013). Identification of agents that can offer alternative treatment for bacterial control is important in the field of health because less toxic substances can combat new pathogens and are more effective against bacteria when required (OSTROSKY et al., 2008; PINHO et al., 2012).
There is a great interest in studying plants with antimicrobial potential, not only because of increased microbial resistance, but also because of the growing need to replace artificial preservatives in food with natural agents (SARTORATTO et al., 2004; MACIEL et al., 2012). Natural substances, especially those from vegetable sources, may have bacteriostatic and bactericidal capacity, which allows them to slow deterioration process, thereby increasing the shelf life of foods (SOUZA et al., 2003).

The Brazilian Cerrado biome is rich in plants containing bioactive chemical compounds that may be 
useful for medical applications and food preservation. Among these plants are genipap, which contains compounds including genipic acids, secoiridoids, tannins, and genipapin (GOTTLIEB \& MORS, 1980; ABRÃO, 2010); baru, which contains triterpenes, isoflavones, and phenolic compounds (PUEBLA et al., 2010); and taruma, which contains butanolid and tarumal (SANTOS et al., 2001; FONSECA et al., 2006).

Although, several species of the Cerrado's plants contain bioactive compounds with natural antimicrobial potential, only a few studies have evaluated their effectiveness. In addition, there has been an increase in microbial resistance to important pathogens, including Staphylococcus aureus, Escherichia coli, Pseudomonas aeruginosa, and Candida albicans. Therefore, the aim of the present study was to evaluate the antimicrobial activity of hydroalcoholic extracts of peel, pulp, and seed of Genipa americana L. (genipap), Dipteryx alata Vog. (baru), and Vitex cymosa Bert. (taruma) against the microorganisms, S. aureus, E. coli, P. aeruginosa, and $C$. albicans.

\section{MATERIALS AND METHODS}

Mature fruits were collected in the city of Campo Grande-MS. Genipap was collected from November 2013 to January 2014 in the central region of the city, baru from August to September 2013, and taruma in December 2013 on the campus of the Universidade Federal do Mato Grosso do Sul.

After cleaning and sanitizing the fruits; peels, pulp, and seeds were separated and homogenized to prepare hydroalcoholic extracts at three concentrations, $10 \%, 20 \%$, and $30 \%(\mathrm{~m} / \mathrm{v})$, according to FARMACOPEIA BRASILEIRA (2010) and adaptations of BITTENCOURT-JUNIOR et al. (2012) and LIMA \& COELHO (2013). Solutions were stored in sealed glass jars, kept at room temperature $\left(25^{\circ} \mathrm{C}\right)$ for 25 days, then filtered through qualitative filter paper (Nalgon, Brazil). Filtrates were evaporated (R-3 Rotaevaporador, Buchi, Brazil) at $50^{\circ} \mathrm{C}$ and the resulting material was resuspended with $20 \mathrm{~mL}$ of $95 \%$ ethanol (Proquímios, Brazil) and subsequently packaged in amber vials at $5^{\circ} \mathrm{C}$.

Strains of $S$. aureus, E. coli, $P$. aeruginosa, and $C$. albicans were obtained from the INCQSInstitute Fiocruz/RJ and were traceable to the American Type Culture Collection (ATCC). For microbial cultivation, Mueller-Hinton broth and agar (Kasvi, Brazil) were used for bacteria and SabouraudDextrose broth and agar (Kasvi, Brazil) were used for fungus. Inocula were prepared in $9 \mathrm{~mL}$ of sterile
$0.9 \%$ saline and their turbidity was compared to a 0.5 McFarland scale tube (Probac, Brazil), corresponding to $1.5 \times 10^{8} \mathrm{CFU} / \mathrm{mL}$ (CLSI, 2005).

Evaluation of antimicrobial activity was performed using disc diffusion tests and the microdilution method proposed by CLSI (2005). The disc diffusion test was performed using sterile filter papers (Sensibiodisc-Cecon, Brazil) impregnated with $50 \mu \mathrm{L}$ of the hydroalcoholic extracts from each piece of fruit, in three concentrations and five replications each, using plates with microorganisms inoculated by a surface seeding technique. Shortly thereafter, the discs were spread on the plates $30 \mathrm{~mm}$ apart. Discs with no reagent served as negative controls and discs with the antimicrobial, azithromycin, served as positive controls.

Susceptibility testing was performed using chloramphenicol, azithromycin, gentamicin, and vancomycin discs (Laborclin, Brazil) for bacteria and nystatin and fluconazole discs (Laborclin, Brazil) for fungus. Bacterial plates were incubated at $35^{\circ} \mathrm{C}$ for $24 \mathrm{~h}$ and fungal plates were incubated at $27^{\circ} \mathrm{C}$ for $42 \mathrm{~h}$. The area of no microbial growth was measured with a caliper rule (Fanem, Brazil) without considering the filter paper disc area $(6 \mathrm{~mm})$ impregnated with the extract (CLSI, 2005; GONÇALVES et al., 2005).

The minimum inhibitory concentration (MIC) and minimum microbicidal concentration (MMC) were determined using the microdilution technique proposed by CLSI (2005). Each measurement was performed in triplicate using 96well microtiter plates (Santa Cruz, Brazil) with enrichment broths (Mueller-Hinton (Kasvi, Brazil) for bacteria and Sabouraud-Dextrose (Kasvi, Brazil) for fungus), serial dilutions of hydroalcoholic extracts, and inoculum. The MIC was determined when no growth was detected in the well of the microplate. A total of $10 \mu \mathrm{L}$ was withdrawn from the microplate and sown in a Petri dish to verify MMC, which was determined when there was no visible microbial growth on the plates.

Statistical analysis for comparison among the concentrations of each of the hydroalcoholic extracts was performed using one-way ANOVA with a Tukey post-test at a significance level of $P<0.05$. To compare the inhibition zones of the extracts for the antimicrobials, a Student's t-test was performed using the GraphPad InStat 3.0 program.

\section{RESULTS}

The results of the susceptibility tests for $S$. aureus, E. coli, and $P$. aeruginosa indicated the 
following inhibition zones, respectively: $9.17 \mathrm{~mm}$, $10.83 \mathrm{~mm}$, and $2.17 \mathrm{~mm}$ for chloramphenicol; $6.33 \mathrm{~mm}$, $5.33 \mathrm{~mm}$, and $6.67 \mathrm{~mm}$ for azithromycin; $7.33 \mathrm{~mm}$, $8.33 \mathrm{~mm}$, and $8.50 \mathrm{~mm}$ for gentamicin; and $5.17 \mathrm{~mm}$ $0.33 \mathrm{~mm}$, and $0.33 \mathrm{~mm}$ for vancomycin. In addition, the results of the $C$. albicans test indicated halos of $4.83 \mathrm{~mm}$ for nystatin and $0.33 \mathrm{~mm}$ for fluconazole.

The results of the disc diffusion tests for the hydroalcoholic extracts are listed in table 1 (genipap), table 2 (baru), and table 3 (taruma).

In the disc diffusion tests with genipap, the $30 \%$ pulp extract displayed the largest inhibition zones against the four microorganisms tested. Regarding baru and taruma, the $30 \%$ pulp extracts displayed the largest inhibition zones against $S$. aureus; however, the largest halos against $E$. coli were obtained with the $30 \%$ peel extract and, against $C$. albicans, with the $30 \%$ seed extract.

Regarding the comparison by t-test of the inhibition halos of extracts with the halos of the susceptibility tests against $S$. aureus, there was no statistically significant difference between azithromycin and the genipap $20 \%$ pulp extract $(\mathrm{P}=0.1256)$ or the genipap $30 \%$ pulp extract $(\mathrm{P}=0.8284)$. In addition, there was no difference between gentamicin and the genipap $30 \%$ pulp extract $(\mathrm{P}=0.2920)$.

There was also no significant statistical difference in tests for $S$. aureus between the antibiotic vancomycin and the genipap extracts: $30 \%$ peel $(\mathrm{P}=0.2959), \quad 20 \%$ pulp $(\mathrm{P}=0.7153), \quad 30 \%$ pulp $(\mathrm{P}=0.1009), 20 \%$ seed $(\mathrm{P}=0.1056)$, and $30 \%$ seed $(\mathrm{P}=0.3552)$, as well as the baru $30 \%$ pulp $(\mathrm{P}=0.1099)$ and $20 \%$ pulp $(\mathrm{P}=0.1048)$ extracts, and taruma $30 \%$ pulp $(\mathrm{P}=0.7342)$ extract. These results indicated that diameters of the inhibition halos of antimicrobials and fruit extracts were similar.

The mean comparison using the Students $\mathrm{t}$-test indicated that there was a significant difference between all the fruit extracts and the antimicrobials, chloramphenicol, azithromycin, and gentamicin $(\mathrm{P}<0.05)$ against $E$. coli. In addition, there was a significant difference between all the fruit extracts and the antibiotics azithromycin and gentamicin $(\mathrm{P}<0.05)$ against $P$. aeruginosa.

There was no significant difference between fluconazole and any of the $10 \%$ and $20 \%$ peel extracts ( $\mathrm{P}=0.2897), \quad 10 \%$ pulp extracts $(\mathrm{P}=0.5995), 10 \%$ seed extracts $(\mathrm{P}<0.9999)$, and $20 \%$ genipap extract $(\mathrm{P}=0.2897)$. In addition, there was no difference between the drug and any extracts of peel, 10\% pulp ( $\mathrm{P}=0.5490), 20 \%$ pulp, $10 \%$ baru seed $(\mathrm{P}=0.2897)$, and all extracts from taruma pulp ( $\mathrm{P}=0.5490)$.

Results of microdilution tests indicated that all genipap extracts displayed MIC and MMC values ranging between $150 \mu \mathrm{g} / \mathrm{mL}$ and $940 \mu \mathrm{g} / \mathrm{mL}$ against all microorganisms (Table 4), whereas baru extracts displayed MIC and MMC values between $150 \mu \mathrm{g} / \mathrm{mL}$ and $1000 \mu \mathrm{g} / \mathrm{mL}$ against all microorganisms except $P$. aeruginosa. Taruma extracts showed no MIC or MMC values against $C$. albicans. These results indicated that only a small amount of extract was necessary for bacteriostatic and bactericidal function against microorganisms tested.

\section{DISCUSSION}

The variable results in this study, such as results where genipap extracts exhibited an MIC

Table 1 - Disc diffusion test of genipap hydroalcoholic extracts (10\%, 20\%, and 30\%) against the microorganisms, Staphylococcus aureus, Escherichia coli, Pseudomonas aeruginosa, and Candida albicans.

\begin{tabular}{|c|c|c|c|c|}
\hline \multirow{2}{*}{$\begin{array}{l}\text { Genipap } \\
\text { Extract }\end{array}$} & \multicolumn{4}{|c|}{ 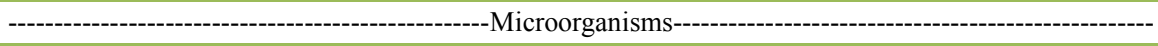 } \\
\hline & S. aureus & E. coli & P. aeruginosa & C. albicans \\
\hline & & --------Peel--- & -----------------. & 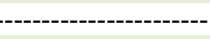 \\
\hline $10 \%$ & $3.33 \pm 0.36^{\mathrm{a}}$ & $1.17 \pm 0.17^{\mathrm{a}}$ & $1.17 \pm 0.17$ & $0.67 \pm 0.21$ \\
\hline $20 \%$ & $3.33 \pm 0.21^{\mathrm{a}}$ & $1.50 \pm 0.22$ & $1.67 \pm 0.21$ & $0.67 \pm 0.21$ \\
\hline $30 \%$ & $4.67 \pm 0.33^{b}$ & $2.33 \pm 0.33^{b}$ & $1.67 \pm 0.21$ & $1.17 \pm 0.17$ \\
\hline ------ & & ---Pulp-------. & ---------------. & 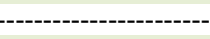 \\
\hline $10 \%$ & $1.17 \pm 0.17^{\mathrm{c}}$ & $1.17 \pm 0.17^{\mathrm{c}}$ & $1.17 \pm 0.17^{\mathrm{a}}$ & $0.50 \pm 0.22^{\mathrm{a}}$ \\
\hline $20 \%$ & $4.83 \pm 0.83^{\mathrm{d}}$ & $2.17 \pm 0.31^{\mathrm{d}}$ & $1.83 \pm 0.17^{\mathrm{b}}$ & $1.17 \pm 0.17$ \\
\hline $30 \%$ & $6.50 \pm 0.67^{\mathrm{e}}$ & $3.16 \pm 0.31^{\mathrm{e}}$ & $2.67 \pm 0.33^{c}$ & $1.50 \pm 0.34^{\mathrm{b}}$ \\
\hline -----. & ----------------. & --Seed--------- & ---------------. & ------------------------ \\
\hline $10 \%$ & $1.50 \pm 0.22^{f}$ & $1.17 \pm 0.17^{\mathrm{f}}$ & $0.33 \pm 0.21$ & $0.33 \pm 0.21^{\mathrm{c}}$ \\
\hline $20 \%$ & $3.50 \pm 0.88$ & $1.50 \pm 0.22^{\mathrm{g}}$ & $0.83 \pm 0.17$ & $0.67 \pm 0.21$ \\
\hline $30 \%$ & $4.33 \pm 0.80^{\mathrm{g}}$ & $3.00 \pm 0.36^{\mathrm{h}}$ & $0.83 \pm 0.17$ & $1.17 \pm 0.17^{\mathrm{d}}$ \\
\hline
\end{tabular}

${ }^{*}$ Averages of five replications of inhibition zones $(\mathrm{mm}) \pm$ standard error of the mean. Different lowercase letters in the same column indicate a significant difference $(\mathrm{P}<0.05)$ in the Tukey post-test. 
Table 2 - Disc diffusion test of baru hydroalcoholic extracts (10\%, 20\%, and 30\%) against the microorganisms, Staphylococcus aureus, Escherichia coli, Pseudomonas aeruginosa, and Candida albicans.

\begin{tabular}{|c|c|c|c|c|}
\hline \multirow{3}{*}{ Baru Extracts } & \multicolumn{4}{|c|}{ 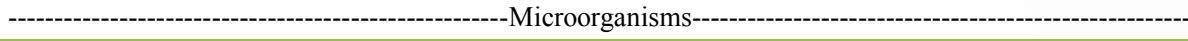 } \\
\hline & S. aureus & E. coli & P. aeruginosa & C. albicans \\
\hline & & ----Peel-------. & & \\
\hline $10 \%$ & $3.33 \pm 0.33$ & $0.17 \pm 0.17^{\mathrm{a}}$ & $0.17 \pm 0.17^{\mathrm{a}}$ & $0.17 \pm 0.17$ \\
\hline $20 \%$ & $3.17 \pm 0.31$ & $1.50 \pm 0.22$ & $0.67 \pm 0.21$ & $0.17 \pm 0.17$ \\
\hline $30 \%$ & $2.67 \pm 0.21$ & $3.00 \pm 0.37^{b}$ & $1.17 \pm 0.17^{\mathrm{b}}$ & $0.17 \pm 0.17$ \\
\hline & & ----Pulp-------- & & \\
\hline $10 \%$ & $4.00 \pm 0.45$ & $0.17 \pm 0.17$ & $1.17 \pm 0.17$ & $0.17 \pm 0.17^{\mathrm{a}}$ \\
\hline $20 \%$ & $4.00 \pm 0.26$ & $0.17 \pm 0.17$ & $1.17 \pm 0.17$ & $0.67 \pm 0.21$ \\
\hline $30 \%$ & $4.50 \pm 0.22$ & $0.17 \pm 0.17$ & $1.17 \pm 0.17$ & $1.17 \pm 0.17^{b}$ \\
\hline$-----\cdot$ & ------------------------ & ----Seed------- & --------------- & ------------------------' \\
\hline $10 \%$ & $0.33 \pm 0.21$ & $0.17 \pm 0.17$ & $0.17 \pm 0.17$ & $0.67 \pm 0.21^{\mathrm{c}}$ \\
\hline $20 \%$ & $0.50 \pm 0.22$ & $0.17 \pm 0.17$ & $0.17 \pm 0.17$ & $1.17 \pm 0.17$ \\
\hline $30 \%$ & $0.67 \pm 0.21$ & $0.17 \pm 0.17$ & $0.17 \pm 0.17$ & $1.67 \pm 0.21^{\mathrm{d}}$ \\
\hline
\end{tabular}

*Averages of five replications of inhibition zones $(\mathrm{mm}) \pm$ standard error of the mean. Different lowercase letters in the same column indicate a significant difference $(\mathrm{P}<0.05)$ in the Tukey post-test.

and MMC against all microorganisms; whereas, baru extracts did not exhibit an MIC or MMC against $P$. aeruginosa and taruma exhibited no activity against $C$. albicans, could be explained by the presence of unknown bioactive compounds in each fruit, which may belong to different families. In addition, the varying results obtained from different parts of the fruits may have been due to secondary metabolites that exist in different concentrations in each part of the fruit.

Rosemary pepper plants and other plants from a study by PINHO et al. (2012) displayed no inhibition halos against $E$. coli, differing from results obtained with the genipap extracts. This may indicate differences in the variation of active compounds present in each plant and the method of extraction of bioactive components.

There were also many similarities in the comparative analysis of the fruit extracts and antimicrobial agents. This was very interesting because the antimicrobial agents are important for the treatment of infections caused by the microorganisms tested and, if therapy alternatives that had similar efficacy and lower side effects were reported, the possible future application as a phytotherapeutic or an antibiotic growth promoter should be verified.

Studies have been performed to evaluate alternatives for the application of plant extracts. TRAESEL et al. (2011), SOUSA et al. (2013), and SANTANA et al. (2015) evaluated the

Table 3 - Disc diffusion test of taruma hydroalcoholic extracts (10\%, 20\%, and 30\%) against the microorganisms, Staphylococcus aureus, Escherichia coli, Pseudomonas aeruginosa, and Candida albicans.

\begin{tabular}{|c|c|c|c|c|}
\hline \multirow{2}{*}{ Taruma extracts } & \multicolumn{4}{|c|}{------------------------------------------------------------Microorganisms------------------------------------------------------ } \\
\hline & S. aureus & E. coli & P. aeruginosa & C. albicans \\
\hline & ---------------- & ------Peel----- & --------------- & --------------- \\
\hline $10 \%$ & $1.17 \pm 0.17^{\mathrm{a}}$ & $0.17 \pm 0.17^{\mathrm{a}}$ & $1.67 \pm 0.21$ & $0.17 \pm 0.17^{\mathrm{a}}$ \\
\hline $20 \%$ & $1.17 \pm 0.17^{\mathrm{a}}$ & $0.17 \pm 0.17^{\mathrm{a}}$ & $1.67 \pm 0.21$ & $0.17 \pm 0.17^{\mathrm{a}}$ \\
\hline $30 \%$ & $2.50 \pm 0.43^{b}$ & $1.17 \pm 0.17^{b}$ & $2.17 \pm 0.17$ & $1.17 \pm 0.17^{\mathrm{b}}$ \\
\hline & -----------------. & -----Pulp---- & ---------------. & 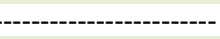 \\
\hline $10 \%$ & $2.50 \pm 0.43^{\mathrm{c}}$ & $0.17 \pm 0.17$ & $1.17 \pm 0.17$ & $0.17 \pm 0.17$ \\
\hline $20 \%$ & $4.00 \pm 0.58^{\mathrm{d}}$ & $0.17 \pm 0.17$ & $1.17 \pm 0.17$ & $0.17 \pm 0.17$ \\
\hline $30 \%$ & $5.00 \pm 0.37^{\mathrm{e}}$ & $0.17 \pm 0.17$ & $1.17 \pm 0.17$ & $0.17 \pm 0.17$ \\
\hline & & -----Seed---- & ----------------- & 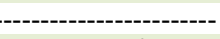 \\
\hline $10 \%$ & $0.17 \pm 0.17^{\mathrm{f}}$ & $0.17 \pm 0.17$ & $1.17 \pm 0.17^{\mathrm{a}}$ & $0.17 \pm 0.17^{\mathrm{c}}$ \\
\hline $20 \%$ & $1.50 \pm 0.22^{\mathrm{g}}$ & $0.17 \pm 0.17$ & $1.50 \pm 0.22$ & $1.00 \pm 0.26$ \\
\hline $30 \%$ & $4.00 \pm 0.37^{\mathrm{h}}$ & $0.17 \pm 0.17$ & $2.17 \pm 0.17^{b}$ & $1.67 \pm 0.21^{\mathrm{d}}$ \\
\hline
\end{tabular}

*Averages of five replications of inhibition zones $(\mathrm{mm}) \pm$ standard error of the mean. Different lowercase letters in the same column indicate a significant difference $(\mathrm{P}<0.05)$ in the Tukey post-test. 
Table 4 - Microdilution tests of genipap, baru, and taruma hydroalcoholic extracts (10\%, 20\%, and 30\%) against microorganisms, Staphylococcus aureus, Escherichia coli, Pseudomonas aeruginosa, and Candida albicans. ${ }^{* *}$

\begin{tabular}{|c|c|c|c|c|c|c|c|c|}
\hline \multirow[t]{2}{*}{ Extracts } & \multicolumn{2}{|c|}{-------S. aureus-------- } & \multicolumn{2}{|c|}{--------E.coli-------- } & \multicolumn{2}{|c|}{----P. aeruginosa------ } & \multicolumn{2}{|c|}{-------C. albicans } \\
\hline & MIC & MMC & MIC & $\mathrm{MMC}$ & MIC & MMC & MIC & MMC \\
\hline Genipap Peel 10\% & 150 & 300 & 150 & 150 & 150 & 150 & 150 & 150 \\
\hline Genipap Peel 20\% & 300 & 620 & 300 & 300 & 300 & 300 & 300 & 300 \\
\hline Genipap Peel 30\% & 470 & 940 & 470 & 470 & 470 & 470 & 470 & 470 \\
\hline Genipap Pulp 10\% & 150 & 300 & 300 & 300 & 150 & 300 & 150 & 150 \\
\hline Genipap Pulp 20\% & 300 & 620 & 620 & 620 & 300 & 620 & 300 & 300 \\
\hline Genipap Pulp 30\% & 470 & 940 & 940 & 940 & 470 & 940 & 470 & 470 \\
\hline Genipap Seed 10\% & 150 & 150 & 620 & 620 & 150 & 300 & 150 & 300 \\
\hline Genipap Seed 20\% & 300 & 300 & 620 & 620 & 300 & 620 & 300 & 620 \\
\hline Genipap Seed 30\% & 470 & 470 & 940 & 940 & 470 & 940 & 470 & 940 \\
\hline Baru Peel 10\% & 620 & 620 & - & - & - & - & - & - \\
\hline Baru Peel 20\% & $>1000$ & $>1000$ & $>1000$ & $>1000$ & - & - & - & - \\
\hline Baru Peel 30\% & $>1000$ & $>1000$ & $>1000$ & $>1000$ & - & - & - & - \\
\hline Baru Pulp 10\% & 620 & 620 & - & - & - & - & - & - \\
\hline Baru Pulp 20\% & $>1000$ & $>1000$ & - & - & - & - & - & - \\
\hline Baru Pulp 30\% & $>1000$ & $>1000$ & - & - & - & - & - & - \\
\hline Baru Seed 10\% & 620 & 620 & - & - & - & - & - & - \\
\hline Baru Seed 20\% & $>1000$ & $>1000$ & - & - & - & - & $>1000$ & $>1000$ \\
\hline Baru Seed 30\% & $>1000$ & $>1000$ & - & - & - & - & $>1000$ & $>1000$ \\
\hline Taruma Peel 10\% & $10 \%$ & $>1000$ & - & - & - & 620 & - & - \\
\hline Taruma Peel $20 \%$ & $20 \%$ & $>1000$ & $>1000$ & - & - & $>1000$ & - & - \\
\hline Taruma Peel $30 \%$ & $30 \%$ & $>1000$ & $>1000$ & $>1000$ & $>1000$ & $>1000$ & - & - \\
\hline Taruma Pulp 10\% & $10 \%$ & 620 & $>1000$ & - & - & 620 & - & - \\
\hline Taruma Pulp 20\% & $20 \%$ & 620 & $>1000$ & - & - & 620 & - & - \\
\hline Taruma Pulp 30\% & $30 \%$ & 940 & $>1000$ & - & - & 940 & - & - \\
\hline Taruma Seed $10 \%$ & $10 \%$ & $>1000$ & - & - & - & - & - & - \\
\hline Taruma Seed $20 \%$ & $20 \%$ & 620 & $>1000$ & - & - & - & - & - \\
\hline Taruma Seed 30\% & $30 \%$ & 940 & 940 & - & - & - & - & - \\
\hline
\end{tabular}

**A Average of triplicates from extracts of concentrations $(\mu \mathrm{g} / \mathrm{mL})$ without detectable growth in microplates Minimum Inhibitory Concentration (MIC) and Minimum Microbicidal Concentration (MMC) in Petri dishes. (-) no MIC or MMC.

supplementation of animal feed for broiler chickens and pigs with essential oils and plant extracts. All of these studies obtained sustainable results, which may also apply to genipap extracts once satisfactory MIC and MMC values are obtained from E. coli and $S$. aureus tests.

Satisfactory results were also obtained from tannin extracts made by KLUG et al. (2016), which reduced the initial microbiome of lettuces during the processing of the vegetables. This indicated the possibility of isolating bioactive compounds from fruits that present antimicrobial activity for the development of sanitizing agents.

The genipap 30\% pulp extract displayed the largest zones of inhibition compared to the other genipap extracts against all microorganisms tested, whereas extracts of baru and taruma pulp showed satisfactory results only against $S$. aureus. This indicated that it may be possible to use fruit pulp in food formulations as a preserving agent.

\section{CONCLUSION}

Genipap, baru, and taruma, displayed potential for antimicrobial activity against the microorganisms, $S$. aureus, E. coli, $P$. aeruginosa, and C. albicans. In particular, the genipap fruit extracts displayed the best zones of inhibition and MIC and MMC values. Further studies should be performed to isolate bioactive compounds and evaluate their pharmacological profiles and applicability of the extracts as antimicrobial agents, food preservatives, alternatives to antibiotic growth promoters, and sanitizing agents. 


\section{ACKNOWLEDGEMENTS}

To Coordenação de Aperfeiçoamento de Pessoal de Nível Superior (CAPES) for Master Degree scholarship and to Fundação Universidade Federal de Mato Grosso do Sul (UFMS) for funding this research.

\section{REFERENCES}

ABRÃO, R. As ervas e a saúde: a farmácia no cerrado. Campo Grande: Cidade gráfica e editora ltda, 2010. 303p.

BARTH, A.L. et al. Resistência bacteriana. In: BARROS, E. et al. Antimicrobianos: consulta rápida. Porto Alegre: Artmed, 2013. Chap.6. p.84-92.

BITTENCOURT-JUNIOR et al. Study of Antibacterial activity of hidroalcoholic extract of Ilex Paraguariensis. Interbio. v.6, n.2, p.4854, 2012. Available from: <http://webcache.googleusercontent.com/ search?q=cache:HRR3irhJeSgJ:www.unigran.br/interbio/paginas/ ed_anteriores/vol6_num2/arquivos/artigo5.pdf $+\& \mathrm{~cd}=1 \& \mathrm{hl}=\mathrm{pt}-$ BR\&ct $=$ clnk\&gl=br>. . Accessed: Feb. 20, 2015.

CLSI. Padronização dos Testes de Sensibilidade a Antimicrobianos por Disco-difusão M2-A8. Wayne: CLINICAL LABORATORY STANDARDS INSTITUTE- CLSI, 2005. 58p.

FARMACOPÉIA BRASILEIRA. Métodos de preparação e análise de extratos vegetais. 5 ed. Brasília: Agência Nacional de Vigilância Sanitária; 2010.V.1, 523p.

FONSECA, E.N. et al. Chemical analysis and antimicrobial activity of the essential oil from Vitex cymosa Bertero. Revista Brasileira de Plantas Medicinais, v.8, n.4, p.87-91, 2006. Available from: $<$ http://www.sbpmed.org.br/download/issn_06_3/artigo16_v8_ n4.pdf>. Accessed: Sep. 01, 2014.

GONÇALVES, A.L. et al. Comparative study on antimicrobial activity of some native tree extracts. Arquivos do Instituto Biológico, v.72, n.3, p.353-358, 2005. Available from: <http:// www.biologico.sp.gov.br/docs/arq/V72_3/goncalves.PDF $>$. Accessed: Mar. 15, 2013.

GOTTLIEB, O.R.; MORS, W.B. Potential utilization of Brazilian wood extractives. Journal of Agricultural and Food Chemistry, v.28, n.2, p.196-215, 1980. Available from: <http://pubs.acs.org/ doi/abs/10.1021/jf60228a023>. Accessed: Jan. 28, 2015. doi: $10.1021 / \mathrm{jf} 60228 \mathrm{a} 023$.

KLUG, T.V. et al. Tannin extracts on quality of fresh cut crisp leaf lettuce. Ciência Rural, v.46, n.8, p.1357-1363, 2016. Available from: <http:/www.scielo.br/scielo.php?script=sci_arttext\& pid $=$ S0103-84782016000801357>. Accessed: Jul. 04, 2016. doi: $10.1590 / 0103-8478 \mathrm{cr} 20151013$.

LIMA, B.R.G.; COELHO, A.F.S. Investigação in vitro da atividade antimicrobiana do extrato do chá Ayahuasca. Higiene Alimentar, v.27, n.220/221, p.121-126, 2013.

MACIEL et al. Evaluation of the alcoholic extract of hibiscus $(\mathrm{Hi}-$ biscus sabdariffaL.) as a protective antibacterial and antioxidant component. Revista do Instituto Adolfo Lutz, v.71, n.3, p.462470, 2012. Available from: <http://periodicos.ses.sp.bvs.br/scielo. php?script $=$ sci_arttext\&pid $=$ S007398552012000300005\&ln$\mathrm{g}=\mathrm{en} \& \mathrm{nrm}=\mathrm{iso}>$. Accessed: Nov. 17, 2015.

OSTROSKY, E.A. et al. Methods for evaluation of the antimicrobial activity and determination of minimum inhibitory concentration (MIC) of plant extracts. Revista Brasileira de Farmacognosia, v.18, n.2, p.301-307, 2008. Available from: $<$ http://www.scielo.br/scielo.php?script=sci_arttext\&pid=S0102695X2008000200026>. Accessed: nov. 27, 2015. doi: 10.1590/ S0102-695X2008000200026.

PINHO, L. et al. Antimicrobial activity of hydroalcoholic extracts from rosemary, peppertree, barbatimão and erva baleeira leaves and from pequi peel meal. Ciência Rural, v. 42, n.2, p.326-331. Available from: <http://www.scielo.br/scielo.php?pid=S0103$84782012000200022 \&$ script $=$ sci_arttext $>$. Accessed: Sep. 12, 2013. doi: 10.1590/S0103-84782012005000003.

PUEBLA, P. et al. Chemical Constituents of the Bark of Dipteryx alata Vogel, an Active Species against Bothrops jararacussu Venom. Molecules. v.15, p.8193-8294, 2010. Available from: $<$ http://www.mdpi.com/journal/molecules $>$ Accessed: Feb. 19, 2015. doi: 10.3390/molecules 15118193 .

SANTANA, M.B. et al. Alternatives to antibiotic growth promoters for weanling pigs. Ciência Rural, v.45, n.6, p.1093-1098, 2015. Available from: <http://www.scielo.br/scielo.php?script=sci_artt ext\&pid=S0103-84782015000601093>. Accessed: Jun. 30, 2016. doi: $10.1590 / 0103-8478 \mathrm{cr} 20140407$.

SANTOS, T.C. et al. Iridoids from Vitex cymosa. Revista da Sociedade Brasileira de Química. v.12, n.6, p.763-766, 2001. Available from: <http://www.scielo.br/scielo.php?pid=s01035053200 $1000600012 \&$ script $=$ sci_arttext $>$. Accessed: Sep. 20, 2013. doi: 10.1590/S0103-50532001000600012.

SARTORATTO, A. et al. Composition and antimicrobial activity of essential oils aromatic plants used in Brazil. Brazilian Journal of Microbiology, v. 35, n.4, p.275-280, 2004. Available from: <http://www.scielo.br/scielo.php?script=sci_arttext\& pid $=$ S151783822004000300001>. Accessed: Nov. 18, 2015. doi: 10.1590/S1517-83822004000300001.

SOUSA, D.R. et al. Supplementation of pink pepper oil and vitamin $\mathrm{E}$ in replacement to antibiotic growth promoters in the broilers diet on response of ileal microbiota. Ciência Rural, v.43, n.12, p.2228-2233, 2013. Available from: <http://www.scielo.br/ scielo.php?script $=$ sci arttext\&pid=S010384782013001200018>. Accessed: Jun. 16, 2016. doi: 10.1590/S0103-84782013005000129.

SOUZA, E.L. et al. Especiarias: uma alternativa para o controle da qualidade sanitária e de vida útil de alimentos, frente às novas perspectivas da indústria alimentícia. Higiene Alimentar, v.17, n.113, p.38-42, 2003.

TRAESEL, C.K. et al. Essential oils as substitutes for antibiotic growth promoters in broilers: soroproteins profile and lipid peroxidation. Ciência Rural, v.41, n.2, p.278-284, 2011. Available from: <http://www.scielo. br/scielo.php?script=sci_arttext\&pid=S010384782011000200016>. Accessed: Jun. 14, 2016. doi: 10.1590/S0103-84782011000200016. 